\title{
A Ruptured Anterior Communicating Artery Aneurysm with Infra-optic Course of the Anterior Cerebral Artery: A Case Report and a Short Review
}

\author{
Katsuhiro TANAKA, ${ }^{1}$ Fujimaro IsHIDA, ${ }^{1}$ Satoru TANIOKA, ${ }^{1}$ and Hidenori SUZUKI ${ }^{2}$ \\ ${ }^{1}$ Department of Neurosurgery, NHO Mie Chuo Medical Center, Tsu, Mie, Japan \\ ${ }^{2}$ Department of Neurosurgery, Mie University Graduate School of Medicine, Tsu, Mie, Japan
}

\begin{abstract}
Infra-optic course of the anterior cerebral artery (IOA) is rare and approximately 55 cases of this anomaly have been described. We present a case of a ruptured anterior communicating artery (ACoA) aneurysm arising at the junction between the left IOA and the bilateral A2 segments, at which the right A1 segment was absent. One of the recurrent arteries of Heubner branched off directly from the aneurysmal dome, and was obstructed at aneurysmal neck clipping via an anterior interhemispheric (AIH) approach. In this report, accompanied anatomical variations and surgical approaches for ACoA aneurysms with IOA are reviewed. An IOA is frequently associated with other vascular anomalies, and the origin of functionally important recurrent arteries of Heubner is also variable. Preoperative accurate evaluation of vessel structures and the maximal exposure at surgery are very important. Pterional approach from the ipsilesional side is reportedly to be safe, but interhemispheric approach is also suggested to be effective as to full exposure to recognize the perianeurysmal anatomical structures including potential vessel anomalies.
\end{abstract}

Keywords: infra-optic course of anterior cerebral artery, anterior communicating artery aneurysm, clipping

\section{Introduction}

An infra-optic course of the anterior cerebral artery (IOA) is a rare anomaly, and there have been approximately 55 cases reported, ${ }^{1-5)}$ of which about half were associated with cerebral aneurysms including anterior communicating artery (ACoA) aneurysms. ${ }^{2,6)}$ IOA is a developmental disorder of the anterior cerebral artery (ACA) during the embryonic period..$^{1,2,7,8)}$ The genesis of IOA remains unclear, but this anomaly originates from the internal carotid artery (ICA) at or close to the level of origin of the ophthalmic artery, running beneath the ipsilateral optic nerve and anterior to the optic chiasm, and then turning upward between bilateral optic nerves to terminate at the ACoA. It is also characterized by associated

Received October 15, 2020; Accepted February 04, 2021

Copyright $@ 2021$ The Japan Neurosurgical Society This work is licensed under a Creative Commons AttributionNonCommercial-NoDerivatives International License. aneurysms and various vascular anomalies. We present a case of a ruptured ACoA aneurysm associated with the IOA, and review previous literatures to discuss surgical strategy based on the anatomical structures.

\section{Case Report}

A female in her seventies was transferred to our hospital with severe headache and vomiting lasting for 4 days. The initial head computed tomography (CT) revealed subarachnoid hemorrhage (SAH) of Fisher CT group 3, and three-dimensional CT angiography and digital subtraction angiography (DSA) showed an ACoA aneurysm, of which the maximum diameter was $5.3 \mathrm{~mm}$, associated with the low bifurcation of the left ICA at the level of the origin of the ophthalmic artery, the left IOA filling bilateral ACA territories, and the right A1 aplasia (Fig. $1 \mathrm{~A}$ and $1 \mathrm{~B}$ ). The anomaly of ACA was also visible on heavily $\mathrm{T} 2$-weighted magnetic resonance images (Fig. 1C-1E). The patient was diagnosed with 

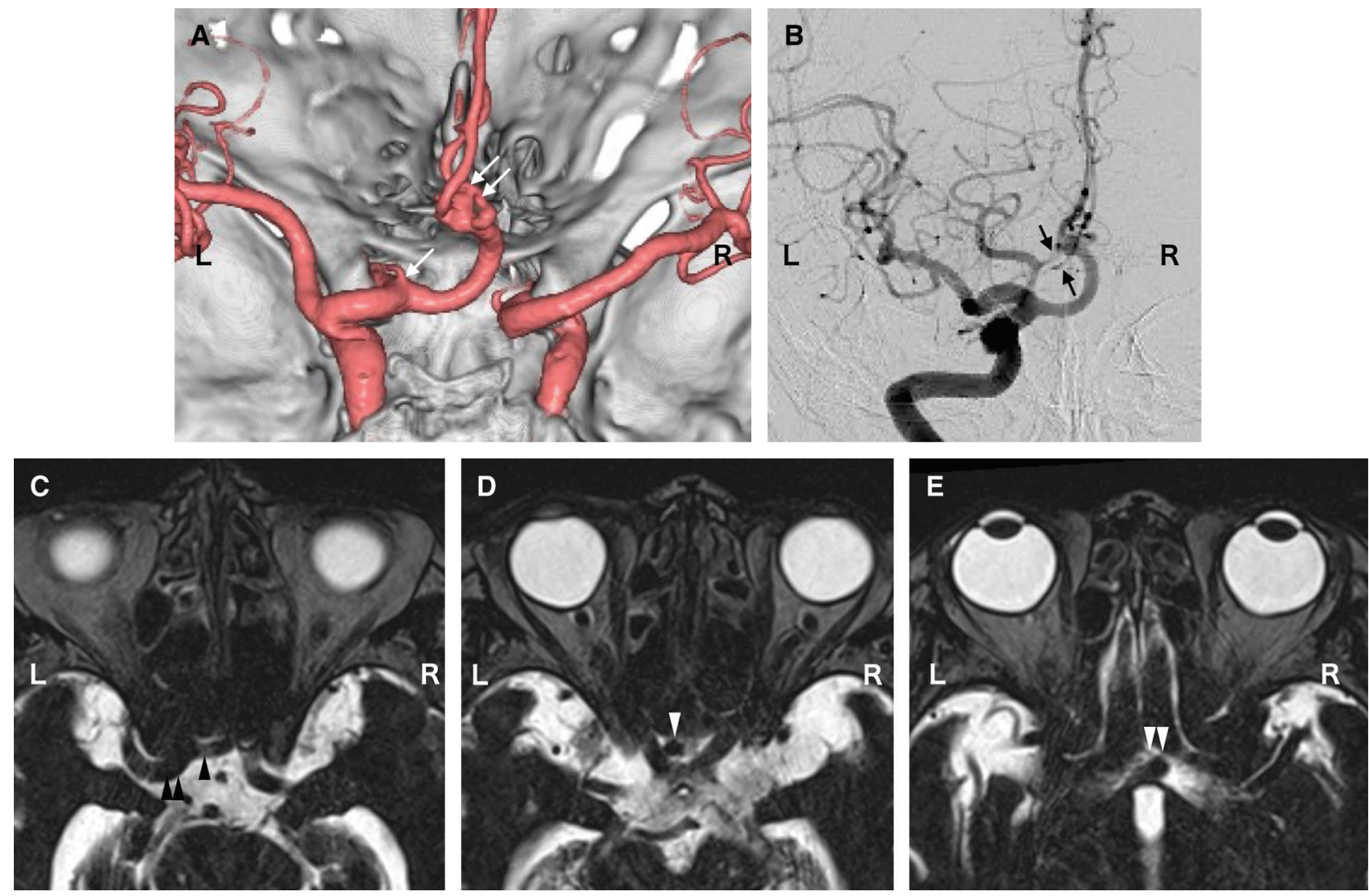

Fig. 1 Preoperative images. CT angiography in the posterior-anterior view reveals the low and early bifurcation of the anomalous ACA at the level of the ophthalmic artery (single white arrow), which turns upward, and an irregular-shaped aneurysm (double white arrow) arises at the junction between this anomalous ACA and bilateral A2 segment of ACAs (A). The left internal carotid angiography (horizontal inversion) shows two recurrent arteries of Heubner (black arrows) and a cortical artery which branch around the aneurysmal neck (B). Heavily T2-weighted magnetic resonance imaging (horizontal inversion) shows the IOA (single black arrowhead) branching from the left ICA (double black arrowheads) beneath the left optic nerve (C), which turns upward between the bilateral optic nerves (single white arrowhead) (D): an IOA aneurysm abuts on the superior part of the lamina terminalis (double white arrowheads) (E). ACA: anterior cerebral artery, CT: computed tomography, ICA: internal carotid artery, IOA: infra-optic course of ACA, L: left, R: right.

aneurysmal SAH of Hunt and Kosnik grade 2 and World Federation of Neurological Surgeons grade 2. As endovascular treatment was considered to be inappropriate due to the irregular shape and a broad neck of the aneurysm, elective surgical clipping was performed at 12 days after the onset of $\mathrm{SAH}$ when a risk of delayed cerebral ischemia passed. As DSA revealed multiple recurrent arteries of Heubner (RAHs) arising around ACoA (Fig. 1B), anterior interhemispheric approach (AIH) was selected to visualize these perforators clearly. The IOA and bilateral fenestrated A2 were found during microsurgical dissection. After full exposure of the aneurysm and main perforators, it was revealed that one of two RAHs branched off directly from the aneurysmal dome and that a small cortical branch adhered to nearby the rupture point (Fig. 2A).
These vessels were interrupted and the ruptured aneurysm was completely obliterated with tandem clipping using 4 Sugita Titanium II clips (17-001-01, 17-001-03, 17-001-81, and 17-001-86; Mizuho Co., Ltd, Tokyo, Japan) to avoid kinking of the bilateral A2 (Fig. 2B). Postoperative magnetic resonance images showed acute infarction in the left caudate head and internal frontal basal cortex owing to the vessels sacrifice (Fig. 2C). The patient had a mild cognitive impairment (modified Rankin scale 3) and was transferred to a rehabilitation facility 28 days after surgery.

\section{Literature Review}

The PubMed database was used to search for previously published articles about ACoA aneurysms 

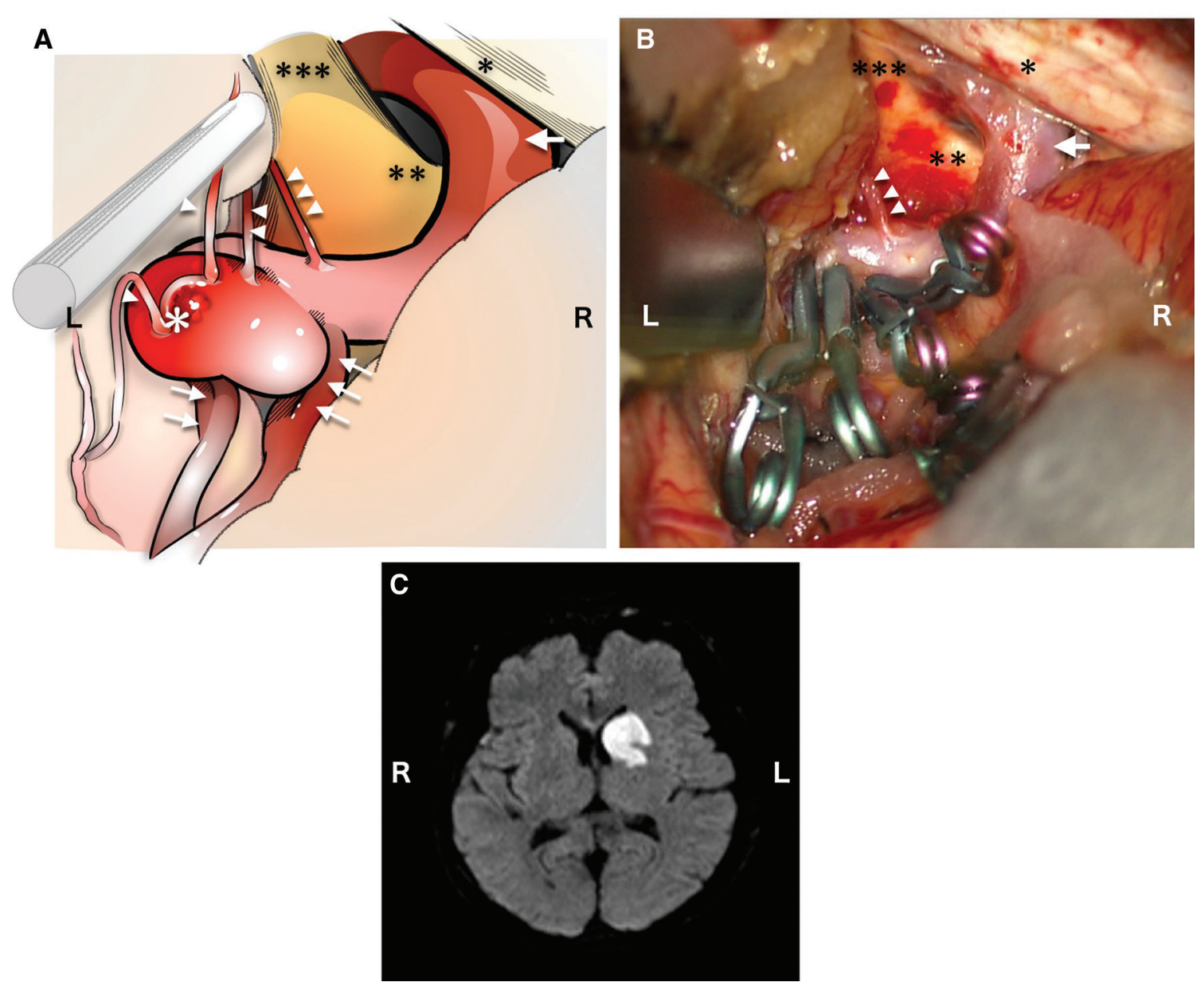

Fig. 2 Intraoperative view of the interhemispheric approach before (illustration; A) and after aneurysmal clipping (photograph; B), and postoperative magnetic resonance imaging (MRI; C). The left IOA (single arrow), left A2 segment with fenestration (double arrows), right A2 segment with fenestration (triple arrows), dura mater of the anterior cranial fossa (single black asterisk), optic chiasm (double black asterisks), the left optic nerve (triple black asterisks), a thrombus at the rupture site of the IOA aneurysm (white asterisk), a cortical artery adhering close to the rupture site (single white arrowhead), one of two RAHs branching from the aneurysm (double white arrowheads), and another RAH branching from the supraoptic portion of the IOA (triple white arrowheads) are illustrated (A). One of two RAHs branching from the aneurysm and the cortical artery adhering close to the rupture site are disconnected and the aneurysm is completely obliterated with multiple clipping (B): the marks in the figure are the same as in A. Postoperative diffusion-weighted MRI reveals acute infarction in the left caudate head and a part of the internal capsule and the putamen (C). IOA: infra-optic course of the anterior cerebral artery, L: left, R: right, RAHs: recurrent arteries of Heubner.

with IOA, which were treated by surgical clipping or coil embolization. The following words were searched: "infra-optic course of anterior cerebral artery," "carotid-anterior cerebral anastomosis," or "anterior cerebral artery anomaly" and "cerebral aneurysm." As a result, 30 cases of ACoA aneurysms with IOA met the purpose of our review and 31 cases including the present case were analyzed regarding their anatomical features, treatment strategies, and outcomes (Table 1)..$^{3-5,9-34)}$ The mean age of patients was $42.5 \pm 14.6$ (standard deviation) years old. The right-sided IOA was dominant (right,
22 cases; left, 2 cases; and bilateral, 7 cases). According to Wong's classification, seven cases belonged to type I, 10 cases to type II, 12 cases to type III, one case to type IV, and one case was undetermined due to missing information. ${ }^{2)}$ As to the treatment, 28 cases of ACoA aneurysms were treated by clipping via a pterional approach (22 cases), an orbitozygomatic approach (one case), or an AIH (four cases including the present case), and the information in one case was unavailable. Three cases were treated by coil embolization with a simple technique in two cases and with a 
Table 1 Cases of ACoA aneurysms with IOA treated with clippig or coiling

\begin{tabular}{|c|c|c|c|c|c|c|c|c|c|c|}
\hline $\begin{array}{l}\text { Author } \\
\text { (year) }\end{array}$ & $\begin{array}{l}\text { Age (years) } \\
\text { / sex }\end{array}$ & $\begin{array}{l}\text { Rupture } \\
\text { state }\end{array}$ & $\begin{array}{l}\text { Side of } \\
\text { IOA }\end{array}$ & $\begin{array}{l}\text { Wong's } \\
\text { classifiation }\end{array}$ & Associated anomaly & $\begin{array}{l}\text { Associated } \\
\text { aneurysm }\end{array}$ & $\begin{array}{l}\text { Branch } \\
\text { from } \\
\text { aneurysm }\end{array}$ & $\begin{array}{l}\text { Surgical } \\
\text { approach }\end{array}$ & $\begin{array}{l}\text { Endovascular } \\
\text { treatment }\end{array}$ & $\begin{array}{l}\text { Postopera- } \\
\text { tive course }\end{array}$ \\
\hline Teal (1973) & $41 / \mathrm{M}$ & SAH & Rt & III & $\begin{array}{l}\text { Persistent primitive } \\
\text { trigeminal artery, Rt } \\
\text { PICA arising from } \\
\text { distal cervical ICA }\end{array}$ & - & - & - & - & - \\
\hline Nutik (1976) & $22 / F$ & SAH & Lt & I & $\begin{array}{l}\text { Lt AICA arising from } \\
\text { cavernous ICA }\end{array}$ & - & - & Lt pterional & - & Uneventful \\
\hline $\begin{array}{l}\text { Kessler } \\
(1979)\end{array}$ & $23 / \mathrm{M}$ & SAH & Rt & I & - & - & - & $\begin{array}{l}\text { Anterior } \\
\text { interhemispheric }\end{array}$ & - & $\begin{array}{l}\text { Regrowth, but } \\
\text { uneventful }\end{array}$ \\
\hline $\begin{array}{l}\text { Lehman } \\
\text { (1980) }\end{array}$ & $23 / \mathrm{M}$ & SAH & Bilateral & II & $\begin{array}{l}\text { Median artery of } \\
\text { corpus callosum, } \\
\text { PCoA arising from } \\
\text { MCA, peripheral } \\
\text { moyamoya vessels, } \\
\text { aortic coarctation }\end{array}$ & - & - & Rt pterional & - & Uneventful \\
\hline $\begin{array}{l}\text { Bernini } \\
(1982)\end{array}$ & $50 / \mathrm{F}$ & $\mathrm{SAH}$ & Rt & I & $\begin{array}{l}\text { PCA arising from } \\
\text { carotid siphon }\end{array}$ & - & - & Rt pterional & - & Uneventful \\
\hline $\begin{array}{l}\text { Senter } \\
(1982)\end{array}$ & $48 / \mathrm{M}$ & $\mathrm{SAH}$ & Rt & III & - & - & - & Rt pterioanl & - & Uneventful \\
\hline $\begin{array}{l}\text { Fujimoto } \\
\text { (1983) }\end{array}$ & $60 / \mathrm{F}$ & $\mathrm{SAH}$ & Rt & II & $\begin{array}{l}\text { Plexiform network of } \\
\text { ACoA }\end{array}$ & - & - & Rt pterional & - & Uneventful \\
\hline $\begin{array}{l}\text { Sasaki } \\
(1984)\end{array}$ & $32 / F$ & SAH & Rt & - & - & - & - & Rt pterional & - & - \\
\hline $\begin{array}{l}\text { Rosenorn } \\
(1985)\end{array}$ & $55 / F$ & SAH & Rt & III & - & - & - & Rt pterional & - & Uneventful \\
\hline Klein (1987) & $43 / \mathrm{F}$ & SAH & Bilateral & II & - & $\begin{array}{l}\text { Rt IOA } \\
\text { aneurysm }\end{array}$ & - & Rt pterional & - & Uneventful \\
\hline Bollar (1988) & $61 / F$ & $\mathrm{SAH}$ & Rt & III & - & - & - & Rt pterional & - & - \\
\hline $\begin{array}{l}\text { Odake } \\
(1988)\end{array}$ & $56 / \mathrm{M}$ & SAH & Rt & III & - & - & - & Rt pterional & - & $\begin{array}{l}\text { Rerupture, } \\
\text { dead }\end{array}$ \\
\hline $\begin{array}{l}\text { Takeshita } \\
\text { (1991) }\end{array}$ & $40 / \mathrm{M}$ & SAH & Rt & II & $\begin{array}{l}\text { Unpaired pericallosal } \\
\text { artery, fenestration } \\
\text { of VA, duplication of } \\
\text { bilateral SCA, Rt OA } \\
\text { arising from ICA }\end{array}$ & - & - & $\begin{array}{l}\text { Anterior } \\
\text { interhemispheric }\end{array}$ & - & Uneventful \\
\hline $\begin{array}{l}\text { Onishi } \\
\text { (1992) }\end{array}$ & $37 / \mathrm{M}$ & SAH & Rt & I & $\begin{array}{l}\text { Skull dysplasia, short } \\
\text { stature }\end{array}$ & - & - & Rt pterional & - & Uneventful \\
\hline $\begin{array}{l}\text { Ladzinski } \\
\text { (1997) }\end{array}$ & $39 / \mathrm{F}$ & SAH & Rt & IV & - & - & - & Rt pterional & - & $\begin{array}{l}\text { Transient } \\
\text { oculomotor } \\
\text { palsy }\end{array}$ \\
\hline Ogura (1998) & $58 / \mathrm{F}$ & $\begin{array}{c}\text { SAH, } \\
\text { ACoA } \\
\text { aneurysm } \\
\text { unruptured } \\
\end{array}$ & Bilateral & II (bilateral) & - & $\begin{array}{l}\text { Bilateral MCA } \\
\text { aneurysm (Rt, } \\
\text { ruptured) }\end{array}$ & - & $\begin{array}{l}\text { Anterior } \\
\text { interhemispheric }\end{array}$ & - & Uneventful \\
\hline
\end{tabular}


Table 1 Continued

\begin{tabular}{|c|c|c|c|c|c|c|c|c|c|c|}
\hline $\begin{array}{l}\text { Author } \\
\text { (year) }\end{array}$ & $\begin{array}{l}\text { Age (years) } \\
/ \text { sex }\end{array}$ & $\begin{array}{l}\text { Rupture } \\
\text { state }\end{array}$ & $\begin{array}{l}\text { Side of } \\
\text { IOA }\end{array}$ & $\begin{array}{l}\text { Wong's } \\
\text { classifiation }\end{array}$ & Associated anomaly & $\begin{array}{l}\text { Associated } \\
\text { aneurysm }\end{array}$ & $\begin{array}{l}\text { Branch } \\
\text { from } \\
\text { aneurysm }\end{array}$ & $\begin{array}{l}\text { Surgical } \\
\text { approach }\end{array}$ & $\begin{array}{l}\text { Endovascular } \\
\text { treatment }\end{array}$ & $\begin{array}{l}\text { Postopera- } \\
\text { tive course }\end{array}$ \\
\hline $\begin{array}{l}\text { Spinatto } \\
\text { (1999) }\end{array}$ & $30 / \mathrm{M}$ & $\begin{array}{c}\text { SAH, } \\
\text { ACoA } \\
\text { aneurysm } \\
\text { unruptured }\end{array}$ & Rt & III & - & $\begin{array}{l}\text { Rt ruptured } \\
\text { MCA aneurysm }\end{array}$ & - & Rt pterional & - & Uneventful \\
\hline $\begin{array}{l}\text { Hillard } \\
(2002)\end{array}$ & $30 / \mathrm{F}$ & SAH & Rt & I & - & - & - & - & $\begin{array}{l}\text { Coiling (simple } \\
\text { tecnique) }\end{array}$ & Uneventful \\
\hline $\begin{array}{l}\text { Al-Qahtani } \\
(2003)\end{array}$ & $11 / \mathrm{M}$ & $\mathrm{SAH}$ & Rt & I & - & - & - & - & $\begin{array}{l}\text { Coiling (simple } \\
\text { tecnique) }\end{array}$ & $\begin{array}{l}\text { IOA occluded, } \\
\text { but uneventful }\end{array}$ \\
\hline Kilic (2005) & $38 / \mathrm{F}$ & SAH & Bilateral & I & Fenestration of ACoA & - & - & Lt pterional & - & Uneventful \\
\hline $\begin{array}{l}\text { McLaughlin } \\
(2007)\end{array}$ & $34 / \mathrm{F}$ & Unruptured & Bilateral & II (bilateral) & $\begin{array}{l}\text { Abnormal gyral } \\
\text { segmentation }\end{array}$ & - & - & Lt pterional & - & Uneventful \\
\hline Yurt (2008) & $35 / \mathrm{M}$ & SAH & Rt & III & - & - & - & Rt pterional & - & Uneventful \\
\hline Cheol (2010) & $28 / F$ & Unruptured & Bilateral & II (bilateral) & - & $\begin{array}{l}\text { Lt MCA } \\
\text { aneurysm }\end{array}$ & - & Lt pterional & - & - \\
\hline Wong (2010) & $45 / \mathrm{M}$ & $\mathrm{SAH}$ & Rt & III & $\begin{array}{l}\text { Median anterior } \\
\text { cerebral artery, } \\
\text { fenestration of } \\
\text { MCA, neither of the } \\
\text { ophthalmic arteries } \\
\text { from ICA }\end{array}$ & - & - & Rt pterional & - & Uneventful \\
\hline $\begin{array}{l}\text { Turkoglu } \\
\text { (2011) }\end{array}$ & $53 / F$ & $\mathrm{SAH}$ & Rt & III & $\begin{array}{l}\text { Rt PICA arising from } \\
\text { ICA, Bilateral SCA } \\
\text { arising from PCA }\end{array}$ & Rt A1 aneurysm & - & $\begin{array}{l}\text { Rt } \\
\text { orbitozygomatic }\end{array}$ & - & Uneventful \\
\hline Kang (2012) & $59 / \mathrm{F}$ & $\mathrm{SAH}$ & Rt & III & Agenesis of Lt ICA & - & - & - & $\begin{array}{l}\text { Coiling } \\
\text { (stent-assisted } \\
\text { technique) }\end{array}$ & Uneventful \\
\hline Chua (2014) & - & Unruptured & Bilateral & II (bilateral) & - & - & - & Rt pterional & - & Uneventful \\
\hline $\begin{array}{l}\text { Kheyreddin } \\
\text { (2019) }\end{array}$ & 44 / M & $\mathrm{SAH}$ & Rt & III & - & - & - & Rt pterional & - & - \\
\hline \multirow{2}{*}{$\begin{array}{l}\text { Nandish } \\
(2019)\end{array}$} & $42 / \mathrm{M}$ & $\mathrm{SAH}$ & Rt & II & - & - & - & Rt pterional & - & Uneventful \\
\hline & $60 / F$ & $\mathrm{SAH}$ & Rt & II & - & - & - & Rt pterional & - & Uneventful \\
\hline $\begin{array}{l}\text { present case } \\
(2020)\end{array}$ & $77 / F$ & $\mathrm{SAH}$ & $\mathrm{Lt}$ & III & $\begin{array}{l}\text { Bilateral fenestrated } \\
\text { A2 }\end{array}$ & - & $\begin{array}{l}\text { Recurrent } \\
\text { artery of } \\
\text { Heubner }\end{array}$ & $\begin{array}{l}\text { Anterior } \\
\text { interhemispheric }\end{array}$ & - & $\begin{array}{l}\text { Mild cognitive } \\
\text { dysfunction }\end{array}$ \\
\hline
\end{tabular}

ACoA: anterior communicating artery, AICA: anterior inferior cerebrellar artery, ICA: internal carotid artery, IOA: infra-optic course of the anterior cerebral artery, Lt: left, MCA: middle cerebral artery, OA: occipital artery, PCA: posterior cerebral artery, PCoA: posterior communicating artery, PICA: posterior inferior cerebellar artery, Rt: right, SAH: subarachnoid hemorrahge, SCA: superior cerebellar artery, VA: vertebral artery, Wong's classification: type I, normal ICA bifurcation with unilateral or bilateral IOA, type II, unilateral or bilateral IOA without supraoptic anterior cerebral artery, type III, unilateral IOA without contralateral A1, type IV, accessory anterior cerebral artery variant with infra-optic course. 
stent-assisted technique in one case. ${ }^{3,26,27)}$ Ruptured ACoA aneurysms with IOA were frequently (44\%) associated with other congenital vessel anomalies (Table 1), ${ }^{3-5,9-23,26-28,30,32,34)}$ and the present case was the first one of an IOA aneurysm with an anomalous branching of a RAH from the aneurysm.

\section{Discussion}

IOA is a known but rarely reported anomaly. In 1959, Robinson first described this ACA anomaly as an autopsy case. ${ }^{1)}$ Approximately 55 cases of this anomaly have been described as carotid-ACA anastomosis, anomalous origin of ACA, or IOA. ${ }^{1-5)}$ The nomenclature is confused due to unclarified embryogenesis of this anomaly. ${ }^{5,8,9,11)}$

Three major hypotheses have been proposed concerning the development of the IOA. Robinson reported the first case of this anomaly as the persistent enlargement of the prechiasmal arterial plexus including the prechiasmal branch of the ophthalmic artery, the superior hypophyseal branch of the ICA, and the chiasmal branch of the ACA. ${ }^{1)}$ Isherwood and Dutton hypothesized this anomaly as the persistence of an anastomotic loop between the primitive dorsal and ventral ophthalmic arteries. ${ }^{7}{ }^{7}$ Bosma explained IOA as the persistence of the embryonic anastomosis between the primitive maxillary artery and the primitive olfactory artery, which is a precursor of ACA. ${ }^{8)}$

Wong et al. ${ }^{32)}$ reviewed 44 cases of IOA including their cases, and classified the various patterns of A1 and IOA configurations into four types according to the presence of the ipsilateral supraoptic A1 and the contralateral A1: type 1 (12 cases), normal bifurcations of the middle cerebral artery and the ACA with unilateral (10 cases) or bilateral (2 cases) IOA; type II (14 cases), unilateral (8 cases), or bilateral (6 cases) IOA with no ipsilateral supraoptic A1 associated with ICA bifurcation at the level of the origin of the ophthalmic artery; type III (10 cases), unilateral IOA with no contralateral A1; and type IV (1 case), an accessory ACA variant with the infraoptic course. The data of the remaining 7 cases were not adequate. In their series, the frequency of associated cerebral aneurysms was $59 \%$ (50\% in type I, $79 \%$ in type II, and $70 \%$ in type III), and ACoA aneurysms were the most common $(100 \%$ in type I-associated aneurysms, $46 \%$ in type II-associated aneurysms, and $67 \%$ in type III-associated aneurysms) ${ }^{2)}$. Based on Padget's and Moffat's articles, ${ }^{35-37)}$ Wong et al. proposed the hypothesis of the development of IOA: that is, a variety of faulty embryogenesis of caudomedial and rostolateral arterial plexuses around the optic vesicle (Padget's stage 1) could lead to type 1 to 4 IOA configuration during Padget's stage $3 .^{2)}$

We reviewed 31 cases of ACoA aneurysms with unilateral or bilateral IOA including our case that were treated by surgical clipping or coil embolization from published literatures (Table 1)..$^{3-5,9-34)}$ ACoA aneurysms were accompanied by all patterns of IOA according to the Wong's classification. As to the surgical approach, 23 of 27 cases of ACoA aneurysms were treated by clipping via a pterional approach and an orbitozygomatic approach. The side of a pterional approach was basically the same side as that of IOA, $4,5,9,10,11,13-16,19,22,23,30,32,34)$ and relatively high-positioned ACoA aneurysms tended to be operated via an orbitozygomatic approach or an AIH including our case. ${ }^{4,6,21)}$ In the present case, complete obliteration of the aneurysm could not avoid the sacrifice of the RAH and resulted in cerebral ischemia in the RAH territory, causing mild cognitive dysfunction. The diverse vascular anomalies around the ACoA associated with IOA may mean highly various branching patterns of functionally important ACA perforators such as the $\mathrm{RAH}$, the hypothalamic artery, and the medial lenticulostriate arteries. Besides, RAH was reported to be multiple in $28 \%$ of 2300 cadaveric cases by Bonasia et $a .^{38)}$ Therefore, it is important to carefully evaluate the perianeurysmal anatomical structures before surgical and endovascular treatment.,239) Surgical clipping via a pterional approach has been reported to be safe, ${ }^{4,5,9,10,11,13-16,19,22,23,30,32,34)}$ but an AIH is also suggested to be reasonable and effective as to full exposure of the perianeurysmal anatomical structures including potential anomalies of the ACA, ACoA, and its perforators. ${ }^{7}$ Alternatively, endovascular treatment of ACoA aneurysms with IOA may be equally feasible depending on their accessibility and morphology, although the importance and limitation of precise detection and preservation of these vessels remain as with surgical treatment. ${ }^{2,3,26,27,39)}$

\section{Conflicts of Interest Disclosure}

The authors declare that they have no conflict of interest.

\section{References}

1) Robinson LR: An unusual human anterior cerebral artery. J Anat 93: 131-133, 1959

2) Wong ST, Yuen SC, Fok KF, Yam KY, Fong D: Infraoptic anterior cerebral artery: review, report of two cases and an anatomical classification. Acta Neurochir (Wien) 150: 1087-1096, 2008 
3) Kang HJ, Lee YS, Suh SJ, Lee JH, Ryu KY, Kang DG: A ruptured aneurysm at the infraoptic azygous anterior cerebral artery with the contralateral internal carotid artery agenesis treated by Y-stent assisted coil embolization. J Cerebrovasc Endovasc Neurosurg 14: 237-242, 2012

4) Turkoglu E, Arat A, Patel N, Kertmen H, Başkaya MK: Anterior communicating artery aneurysm associated with an infraoptic course of anterior cerebral artery and rare variant of the persistent trigeminal artery: a case report and literature review. Clin Neurol Neurosurg 113: 335-340, 2011

5) Nandish HS, Selvapandian S, Ghosh S: Surgical significance of infra-optic course of A1 segment of anterior cerebral artery: report of two cases. Asian J Neurosurg 14: 927-929, 2019

6) Katoh M, Kamiyama H, Makino K, et al: Infra-optic course of the anterior cerebral artery. J Clin Neurosci 6: 252-255, 1999

7) Isherwood I, Dutton J: Unusual anomaly of anterior cerebral artery. Acta Radiol Diagn (Stockh) 9: 345-351, 1969

8) Bosma NJ: Infra-optic course of anterior cerebral artery and low bifurcation of the internal carotid artery. Acta Neurochir (Wien) 38: 305-312, 1977

9) Nutik S, Dilenge D: Carotid-anterior cerebral artery anastomosis. Case report. J Neurosurg 44: 378-382, 1976

10) Kessler LA: Unusual anomaly of the anterior cerebral artery: report of a case. Arch Neurol 36: 509-510, 1979

11) Senter HJ, Miller DJ: Interoptic course of the anterior cerebral artery associated with anterior cerebral artery aneurysm. Case report. J Neurosurg 56: 302-304, 1982

12) Teal JS, Rumbaugh CL, Segall HD, Bergeron RT: Anomalous branches of the internal cartoid artery. Radiology 106: 567-573, 1973

13) Lehmann G, Vincentelli F, Ebagosti A: Rare abnormalities of the circle of Willis: infra-optic pathway of the anterior cerebral arteries (author's transl). Neurochirurgie 26: 243-246, 1980

14) Bernini FP, Cioffi FA, Muras I, Rinaldi F: Carotid syphon--pericallosal arterial anastomosis. Case report. Acta Neurochir (Wien) 66: 61-69, 1982

15) Fujimoto S, Murakami M: Anomalous branch of the internal carotid artery supplying circulation of the anterior cerebral artery. Case report. J Neurosurg 58: 941-946, 1983

16) Sasaki T, Usami T, Takeda R, et al: Three cases of infra-optic course of the anterior cerebral artery. No Shinkei Geka 12: 953-958, 1984 (Japanese)

17) Rosenørn J, Ahlgren P, Rønde F: Pre-optic origin of the anterior cerebral artery. Neuroradiology 27: 275277, 1985

18) Klein SI, Gahbauer H, Goodrich I: Bilateral anomalous anterior cerebral artery and infraoptic aneurysm. AJNR Am J Neuroradiol 8: 1142-1143, 1987

19) Bollar A, Martinez R, Gelabert M, Garcia A: Anomalous origin of the anterior cerebral artery associated with aneurysm-embryological considerations. Neuroradiology 30: 86, 1988

20) Odake G: Carotid-anterior cerebral artery anastomosis with aneurysm: case report and review of the literature, Neurosurgery 23: 654-658, 1988

21) Takeshita M, Kubo O, Onda H, et al: A case showing the infraoptic course of the anterior cerebral artery associated with anterior cerebral artery aneurysm. No Shinkei Geka 19: 871-876, 1991 (Japanese)

22) Onishi H, Yamashita J, Enkaku F, Fujisawa H: anomalous origin of the anterior cerebral artery and congenital skull dysplasia--case report. Neurol Med Chir (Tokyo) 32: 296-299, 1992

23) Ladziński P, Maliszewski M, Majchrzak H: The accessory anterior cerebral artery: case report and anatomic analysis of vascular anomaly. Surg Neurol 48: 171-174, 1997

24) Ogura K, Hasegawa K, Kobayashi T, Kohno M, Hondo $\mathrm{H}$ : A case of bilateral infraoptic course of ACA associated with multiple cerebral artery aneurysms. No Shinkei Geka 26: 525-530, 1998 (Japanese)

25) Spinnato S, Pasqualin A, Chioffi F, Da Pian R: Infraoptic course of the anterior cerebral artery associated with an anterior communicating artery aneurysm: anatomic case report and embryological considerations Neurosurgery, 44:1315-1319, 1999.

26) Hillard VH, Musunuru K, Nwagwu C, et al: Treatment of an anterior communicating artery aneurysm through an anomalous anastomosis from the cavernous internal carotid artery. J Neurosurg 97: 14321435, 2002

27) Al-Qahtani S, Tampieri D, Brassard R, Sirhan D, Mellanson D: Coil embolization of an aneurysm associated with an infraoptic anterior cerebral artery in a child. AJNR Am J Neuroradiol 24: 990-991, 2003

28) Kiliç k, Orakdöğen M, Bakirci A, Berkman Z: Bilateral internal carotid to anterior cerebral artery anastomosis with anterior communicating artery aneurysm: technical case report. Neurosurgery 57: E400; discussion E400, 2005

29) McLaughlin N, Bojanowski MW: Infraoptic course of anterior cerebral arteries associated with abnormal gyral segmentation. Case report. J Neurosurg 107: 430-434, 2007

30) Yurt A, Uçar K, Ozer F, Oran I, Arda N: A rare embryologic variation: anterior communicating artery aneurysm associated with carotid-anterior cerebral artery anastomosis or infraoptic course of the anterior cerebral artery. Clin Med Case Rep 1: 123-125, 2008

31) Ji C, Ahn JG: Infraoptic course of both anterior cerebral arteries. J Korean Neurosurg Soc 47: 71-73, 2010

32) Wong GK, Wang K, Yu SC, Poon WS: A rare anatomical variant median anterior cerebral artery fenestration associated with an azygous infra-optic anterior cerebral artery. J Clin Neurosci 17: 1434-1436, 2010

33) Chua MH, Thomas AJ, Fusco MR, Ogilvy CS: An unruptured anterior communicating artery aneurysm with bilateral infraoptic anterior cerebral arteries. Case report and review of the literature. J Cerebrovasc Endovasc Neurosurg 16: 368-373, 2014 
34) Kheyreddin AS, Kaftanov AN, Sazonov IA: Combination of infraoptic anterior cerebral artery with an aneurysm of the ACA-AcomA complex. Case study and literature review. Zh Vopr Neirokhir Im $N$ N Burdenko 83: 82-89, 2019 (Russian)

35) Padget DH: The development of the cranial arteries in the human embryo. Contrib Embryol 32: 205-261, 1948

36) Moffat DB: The development of the anterior cerebral artery and its related vessels in the rat. Am J Anat 108: 17-29, 1961

37) Moffat DB: The embryology of the arteries of the brain. Ann R Coll Surg Engl 30: 368-382, 1962
38) Bonasia S, Bojanowski M, Robert T: Embryology and variations of the recurrent artery of Heubner. Neuroradiology 62: 427-437, 2020

39) Tahir RA, Haider S, Kole M, Griffith B, Marin H: Anterior cerebral artery: variant anatomy and pathology. J Vasc Interv Neurol 10: 16-22, 2019

Corresponding author: Katsuhiro Tanaka Department of Neurosurgery, NHO Mie Chuo Medical Center, 2158-5 Hisaimyojicho, Tsu, Mie 514-1101, Japan.

e-mail: tk_0303_ns@yahoo.co.jp 